P-ISSN : 2715-744X

\title{
HOMO SACER ORANG PEGATEN DALAM NOVEL KUBAH KARYA AHMAD TOHARI (PERSPEKTIF GIORGIO AGAMBEN)
}

\author{
Oleh \\ Wista Ayu Pratiwi \\ Pascasarjana UGM, Fakultas Ilmu Budaya \\ Wistaayupratiwi95@gmail.com \\ Tristanti Apriyani \\ Dosen Prodi Sastra Indonesia UAD \\ tristanti.apriyani@idlitera.uad.ac.id
}

DOI:

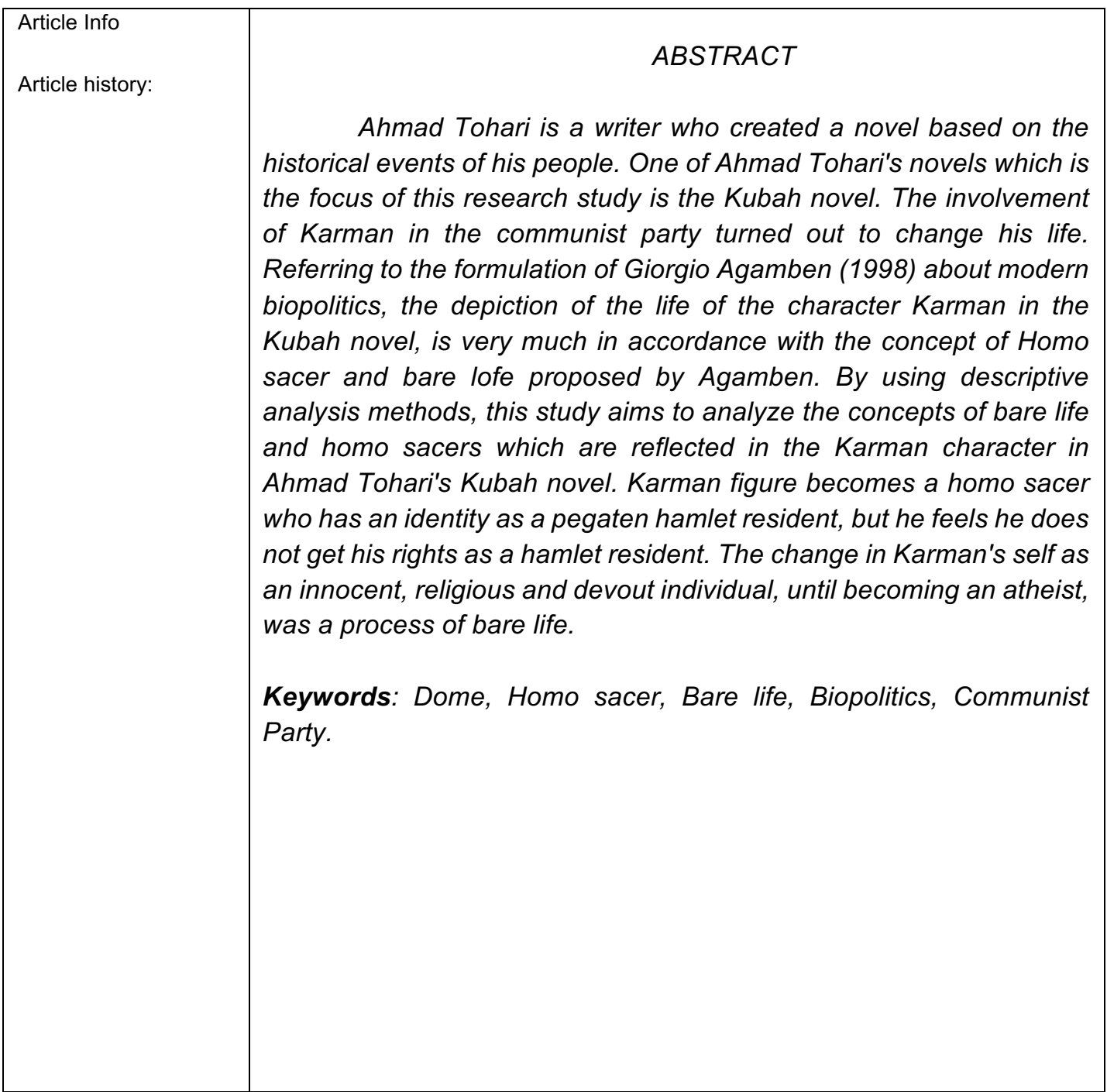




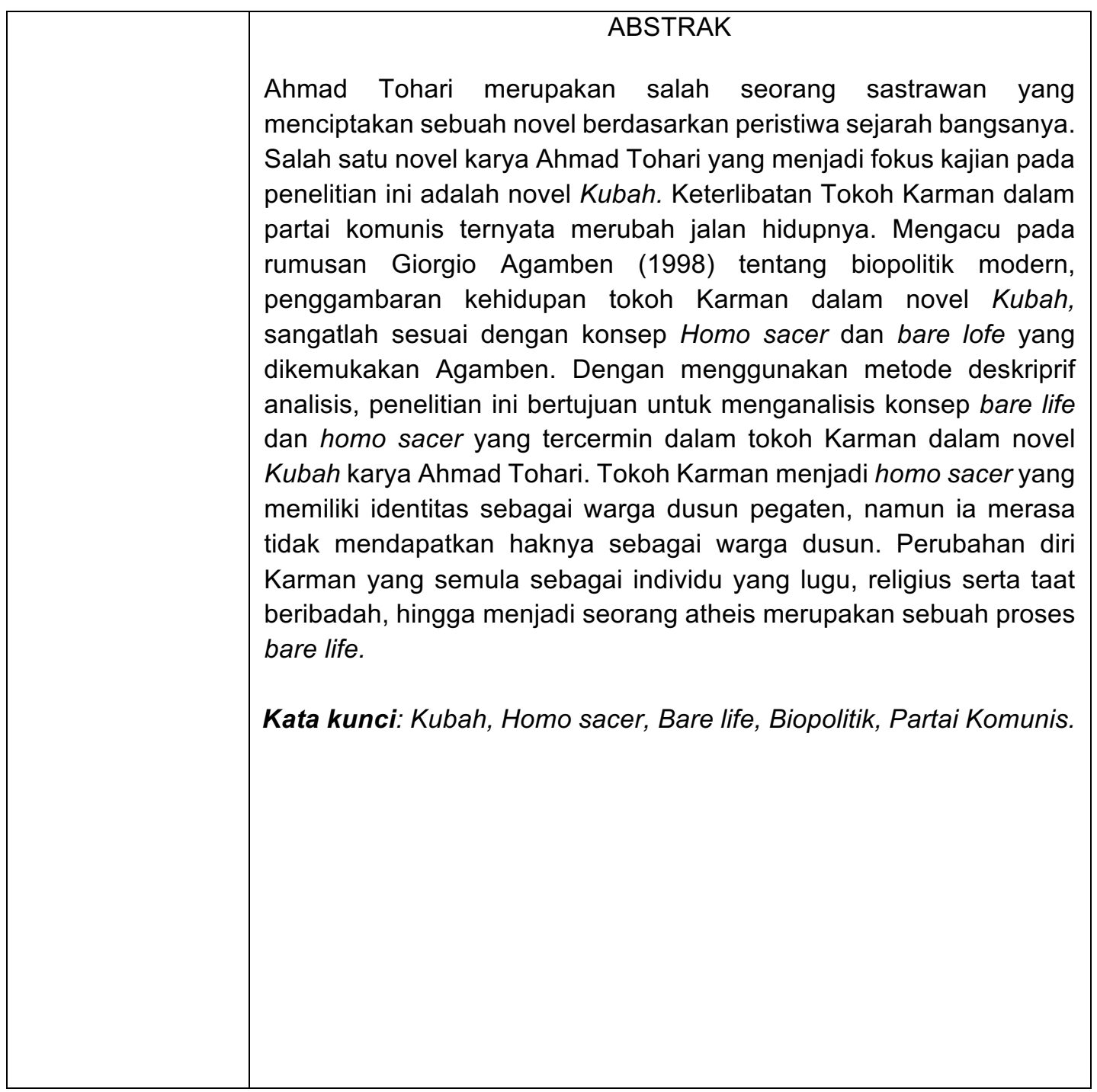

\section{PENDAHULUAN}

Beberapa sastrawan menciptakan karyanya karena didorong oleh keinginan dan perhatiannya terhadap fenomena sosial di sekitarnya, termasuk peristiwa sejarah yang dialami bangsanya. Buah hasil karya para sastrawan, banyak diilhami dari peristiwa sejarah yang dialami bangsa Indonesia. Sejalan dengan rumusan Wellek dan Warren (2016: 38) bahwa karya sastra dapat dipandang sebagai sebuah deretan karya yang tersusun secara kronologis dan merupakan bagian dari proses sejarah. Ahmad Tohari merupakan salah seorang sastrawan yang menciptakan sebuah novel berdasarkan peristiwa sejarah bangsanya.

Ahmad Tohari tergolong sastrawan produktif yang karya-karyanya banyak mengangkat masalah-masalah sosial. Sebagai sastrawan yang berasal dari desa, Ahmad Tohari selalu mewarnai karyanya dengan gambaran kehidupan masyarakat desa. 
Kepiawaian dan kekhasannya menulis membuat karya sastranya diterbitkan di berbagai negara dan diterjemahkan ke dalam berbagai bahasa, seperti bahasa Jepang, bahasa Mandarin, Jerman, dan Belanda. Tidak mengherankan jika karya Ahmad Tohari mendapatkan berbagai penghargaan.

Salah satu novel karya Ahmad Tohari yang menjadi fokus kajian pada penelitian ini adalah novel Kubah. Novel Kubah mengisahkan permasalahan yang dialami oleh pemuda miskin yang baik, tulus, cerdas dan lugu bernama Karman di sekitar tahun 1965. Akibat keluguannya Karman harus menerima penderitaan lahir batin karena keterlibatannya dalam sebuah partai politik yakni PKI atas kesadarannya sendiri. Karman mengambil langkah untuk terlibat di partai komunis karena ia sadar akan keterbatasan dirinya. Pendidikannya rendah sehingga lapangan pekerjaan yang tersedia dan cocok untuknya pun menjadi terbatas.

Keterlibatan Tokoh Karman dalam partai komunis ternyata merubah jalan hidupnya. Sejalan dengan yang dikemukakan Agamben (1998:8) bahwa politik seakanakan merupakan tempat di mana kehidupan harus merubah dirinya menjadi kehidupan yang baik. Dalam hal ini politik dianggap sebagai kehidupan yang natural atau "bare life". Salam (2018:35) mengemukakan bahwa paradigma Agamben merupakan sebuah pengetahuan dengan model kerangka logika bipolar yang berasal dari persimpangan antara diakronis dan sinkronis dari segala fenomena dan bentuk.

Karman tidak mendapatkan kehidupan yang baik sebelum bahkan sesudahnya ia bekerja menjadi kader partai. Karman digambarkan sebagai subjek dan objek dalam konflik politik. Pada partai komunis Karman dijadikan sebagai alat bahkan di desa Pegaten ia dianggap sebagai benih konflik. Kehidupan alami manusia telah dijadikan subjek hukum oleh kedaulatan negara sehingga mendapatkan perlindungan atas hak-haknya sebagai manusia (Agamben, 1998:126). Manusia memiliki dua hak yaitu: hak pasif dan hak aktif. Hak pasif merupakan hak yang diperoleh karena ia adalah manusia. Artinya semua manusia memiliki hak pasif tersebut. Sementara hak aktif adalah hak-hak seseorang yang merupakan anggota dari kelompok secara keseluruhan dan tidak semua orang memiliki hak ini (Agamben, 1998:130). Oleh karena itu, setiap manusia semestinya memiliki jaminan hak asasi sebagai warga negara.

Mengacu pada rumusan Agamben (1998) tentang biopolitik modern, penggambaran kehidupan tokoh Karman dalam novel Kubah sangatlah sesuai dengan konsep Homo sacer dan bare lofe yang dikemukakan Agamben. Zoe merupakan sebuah kehidupan alami yang dimiliki oleh makhluk hidup, sedangkan konsep bios menunjukkan pada kualitas kehidupan yang diidamkan dalam sebuah kelompok politik. Agamben (1998) mengemukakan bahwa zoe terkungkung dalam aturan politik dan selanjutnya dijadikan sebagai subjek dan objek konflik politik. Oleh karena itu, ketika kehidupan tokoh Karman tidak menunjukkan kualitas kehidupan yang diidealkan dalam sebuah partai politik (bios), maka akan terbentuk apa yang oleh Agamben disebut dengan bare life.

Agamben (Agamben, 1998:8) merumuskan bahwa pada akhirnya bare life ini akan menghasilkan sebuah Homo sacer. 
Dalam konsep biopolitik yang dikemukakan Agamben (1998:10) hidup manusia menjadi identik dengan fungsi administrasi negara. Individu sebagai warga negara yang merdeka harus siap untuk mau diatur oleh negara. Keberadaan dan kehidupan rakyat dihadirkan dan dilindungi sepenuhnya dalam representasi Negara.

Hal ini tampak pada penggambaran tokoh Karman dalam novel Kubah yang mengalami proses politisasi kehidupan. Ketika ia terbebas dari tahanan di Pulau Buru selama dua belas tahun, ia mulai dihantui rasa bersalah karena sudah melanggar semuah aturan dalam kehidupan bernegara. Ia memilih masuk ke dalam sebuah partai politik terlarang. Karman harus menjalani kehidupan alamiahnya di tengah pertarungan politik. Oleh karena kesalahannya itu, ia memiliki hak-hak asasinya sebagai warga negara secara utuh. Karman tidak memiliki hak-hak politik sebagai warga sebuah negara. Hak asasinya seolah-olah dibunuh dan sebagai manusia Karman merasa tidak dapat berbuat apa-apa (homo sacer). Dalam konsep yang dikemukakan Agamben (1998:47) pada akhirnya tokoh Karman dalam novel Kubah dapat mentransformasikan kehidupan alamiahnya, menjadi kehidupan yang diidamkan sebuah kelompok politik di dalam sebuah negara (bare life).

Menurut Salam (2018:46) seharusnya peran negara dibutuhkan untuk melindungi kepentingan bangsa. Bangsa yang dimaksud adalah sebagai sebuah komunitas imaginer yang bersifat terbatas dan berdaulat. Negara hendaknya bertindak dengan cara memisahkan antara warga negaranya dan bukan warga negaranya. Salam (2018:46) selanjutnya mengutip kategori jenis kewarganegaraan dalam masyatakat yang dirumuskan Zolov and Rogers (2010) yaitu kewarganegaraan sosial yang diartikan sebagai rasa memiliki atau menjadi bagian dari suatu negara dan berpartisipasi secara aktif dalam kehidupan sosial, 2) kewarganegaraan politik, dan 3) kewarganegaraan sipil yang diakui negara sebagai bagian dari negara dan dilindungi hak-haknya dari negara.

Menyimak penggambaran tokoh Karman berkenaan dengan perubahan sikap dan pemikirannya menjadi hal yang menarik untuk diteliti. Perubahan pribadi Karman yang pada awalnya sebagai sosok religius, berubah menjadi ateis karena keterlibatannya di partai politik komunis. Peristiwa pengasingan di Pulau Buru membuat Karman menyadari bahwa dirinya adalah makhluk yang benar-benar jauh dari segalanya. Kesalahannya untuk terlibat di partai politik mengantarkan Karman menuju penderitaan yang bahkan ia tidak sanggup untuk menerima dan menjalaninya. Penelitian ini bertujuan untuk menganalisis tokoh Karman dalam novel Kubah karya Ahmad dalam perspektif biopolitik modern yang dirumuskan Giorgio Agamben, yaitu gambaran konsep bare life dan homo sacer yang tercermin dalam tokoh Karman.

\section{METODE}

Mengacu pada tujuan penelitian yang telah disebutkan di atas, penelitian ini merupakan jenis penelitian kualitatif yang menggunakan metode deskriprif analisis. Langkah-langkah dalam metode penelitian deskriptif analisis dimulai dengan memaparkan data-data berupa diksi tertulis 
(Moleong, 2008) dilanjutkan dengan proses analisis (Ratna, 2010:53).

Teknik pengumpulan data yang dilakukan menggunakan teknik baca simbolik dan semantik, teknik catat quoatasi, dan teknik parafrase dengan mengelompokkannya sesuai dengan kategori data yang dibutuhkan (Kaelan, 2012: 164167). Novel Kubah karya Ahmad Tohari dijadikan sebagai sumber data primer, sedangkan data penunjang berupa buku-buku dan artikel tentang pemikiran Giorgio Agamben, artikel dalam jurnal yang membahas tentang teori sosiologi sastra dan penelitian sastra.

Sementara itu, teknik analisis deskriptif yang dilakukan dalam penelitian ini adalah teknik analisis deskriptif model Miles dan Hubermas (2014:30) yaitu dengan membaca novel Kubah serta memahami isi novel tersebut. Langkah selanjutnya adalah mendeskripsikan dan menganalisis konsep biopolitik modern yang dikemukakan Giorgio Agamben. Penarikan kesimpulan sebagai jawaban dari permasalahan yang dikemukan, merupakan langkah terakhir dari proses penelitian ini. Untuk keabsahan data, penelitian ini melakukan proses triangulasi data berupa triangulasi teori, triangulasi sumber data, dan triangulasi peneliti.

\section{HASIL DAN PEMBAHASAN}

\section{Homo sacer yang tercermin pada tokoh Karman}

Konsep Homo sacer yang dikemukakan Agamben (1998) menunjukkan batasan manusia sebagai individu yang masih disebut manusia, namun tidak memiliki kapasitas untuk berfungsi sebagai manusia sesusai dengan tuntutan suatu kelompok masyarakat (Indrajaya, 2011:338). Dalam novel Kubah, Homo Sacer yang tercermin pada tokoh Karman dapat dicermati dari kutipan berikut.

"Oh, kota kabupaten ini benar-benar sudah berubah. Dan anehnya perubahan yang tampak merata di depan mata itu membuat Karman merasa makin terasing. Sangat jelas ada garis pemisah yang tajam antara dirinya dan alam sekitar. Ia merasa tidak menjadi bagian dari bumi dan lingkungan yang sedang dipijaknya." (Kubah, Hal 7).

Tidak lama setelah terjadi peristiwa berdarah tanggal 30 September 1965, Margo, Triman, dan orang terdekatnya mati terbunuh. Karman yang ketakutan berusaha untuk melarikan diri. Sewaktu bersembunyi, Karman merasa menyesal telah bergabung ke dalam partai yang melakukan kekejaman secara tidak manusiawi. Pada akhirnya Karman ditangkap di sebuah gubuk dalam keadaan hampir pingsan. Karman selanjutnya dibawa ke Pulau Buru sebagai tahanan politik. Belum selesai masa tahanan, Karman harus merelakan istrinya menikah dengan Parta. Hal ini sangat mempengaruhi kondisi kejiwaan Karman.

Setelah peristiwa 30 September 1965, Margo dan Triman mati terbunuh. Karman berusaha melarikan diri dan bersembunyi. Selama dalam persembunyiannya itu Karman menyesali atas apa yang telah dilakukannya. Ia telah salah bersikap dengan bergabung di partai politik. Ia menyesal telah menjadi seorang atheis dan melakukan kekejaman yang tidak manusiawi. 
Pada akhirnya ia tertangkap dalam sebuah gubuk dalam keadaan hampir pingsan. Karman pun dijadikan politik dan diasingkan selama dua belas tahun di Pulau Buru. Setelah bebas dari Pulau Buru, Karman kembali ke Pegaten dan memandang sekitarnya yang mengalami banyak sekali perubahan, Karman merasa asing. Karman merasa bahwa seolah dirinya ditolak oleh lingkungannya.

Setelah keluar dari pengungsiannya, tokoh Karman seolah-olah menjadi seorang manusia yang memiliki identitas (berkewarganegaraan tertentu), akan tetapi seperti tidak memiliki identitas. Kondisi Karman seperti ini yang dijelaskan Agamben (1998) sebagai Homo sacer yaitu sebuah figure yang makna keberadaannya melampaui norma moral yang ada dan hukum yang berlaku. Karman seperti orang asing di daerahnya sendiri.

Sebenarnya Margo yang menyebabkan Karman harus menanggung tersebut. Dapat dikatakan Margo adalah guru Karman sekaligus memanfaatkannya. Tokoh Karman awalnya digambarkan pengarang sebagai seorang yang taat menjalankan perintah agama. Akan tetapi, kekecewaannya terhadap kegagalan pernikahannya menjadikannya berubah. Ia makin jarang bersembahyang. Keadaan ini tidak disiasiakan oleh Triman dan Margo. Kebetulan Karman sangat membutuhkan pekerjaan. Mulailah Triman dan Margo menanamkan benih-benih paham komunisme ke dalam pikiran Karman. Akhirnya Karman pun terpengaruh dengan aktif menjadi anggota partai dan mulai meninggalkan kebiasaannya dalam beribadah.

Margo mengetahui bahwa Karman sedang membutuhkan pekerjaan. Oleh karena itu dengan sigap ia membujuk dan meyakinkan karman untuk dapat bergabung sebagai anggota partai komunis. Apalagi Margo sangat memahami kondisi Karman yang baru saja terpuruk karena kegagalan pernikahannya. Seperti yang tertera dalam kutipan berikut.

"Margo, seorang kader partai yang cerdik, amat pandai merekayasa kehalusan hati Karman demi kepentingan politiknya." (Kubah, Hal 78).

Margo sebetulnya merupakan tokoh keturunan Muso, seorang komunis penggerak makar di Madiun. Margo diangkat sebagai anggota partai komunis ketika masih menjadi pelajar. Sama seperti Karman, Margo pun merupakan sosok yang cerdas dan ulet. Margo pun terjun di partai politik karena dimanfaatkan oleh Muso. Pada sebuah pertemuan partai, Margo menjelaskan tentang Karman kepada atasannya. Seperti pada bagian kutipan berikut.

"Apabila laporan kawan Margo

benar, saya pun berpendapat bahwa Karman bisa dijadikan bibit unggul." (Kubah, Hal 86).

Pernyataan Margo tentang bibit unggul didasarkan atas pengamatannya terhadap karman. Karman dinilai memiliki kecerdasan yang mumpuni. Meski Karman hanya lulusan sekolah menengah, namun pendidikan itu lebih tinggi dibandingkan dengan pemuda lainnya di Pegaten. Dalam hal ini Karman berubah menjadi individu yang berbeda. Semula dia menjadi individu yang taat menjalankan ibadah, dan setelah aktif di partai politik ia menjadi pribadi yang 
ateis. Karman menjadi ateis karena kebutuhannya akan pekerjaan. Dalam hal ini Karman menjadi Homo sacer, manusia yang bukan manusia.

$$
\text { Pada kutipan selanjutnya }
$$
digambarkan bahwa tokoh Karman hanya mengetahui bahwa dirinya akan bekerja sebagai seorang pegawai, dan di mata Karman bahwa sosok Triman membawa pengaruh yang baik bagi Karman, hal tersebut membuat Karman dapat membalas budi terhadap orang-orang yang telah baik kepadanya, salah satunya terhadap Triman untuk setidaknya bersikap lebih hormat. Seperti halnya pada kutipan berikut.

"Karman merasa tak bisa berbuat lain kecuali bersikap hormat kepada para penolongnya." (Kubah, Hal 96).

Pada akhirnya Karman menyadari bahwa satu demi satu para anggota partai komunis tertangkap dan Karman pada akhirnya menjadi seorang yang diburu. Karman merasa bahwa dirinya terasingkan dan bahkan merasa khawatir masyarakat Pegaten tidak akan menerimanya lagi. Seperti pada kutipan berikut.

"Ya, Karman sadar dirinya kini menjadi manusia buruan, sebuah sebutan yang amat rendah dan tak pernah terbayangkan bisa terjadi atas dirinya." (Kubah, hal 156)

"Karman merinding dan merasakan dirinya susut menjadi mahluk kecil yang tak berguna. Atau malah menyusahkan masyarakat dan karenanya harus diburu dan dihukum?" (Kubah, hal 159)

Di saat dalam pengasingan Karman mulai gelisah memikirkan dirinya. Ia membayangkan kehidupannya kelak setelah dia keluar dari pengasingan. Karman mulai mempertanyakan apakah dirinya akan tetap diakui keberadaannya di masyarakat, ataukah sebaliknnya dan bahkan menjadi orang yang terlupakan. Kegelisahan Karman tampak pada kutipan berikut ini.

"Apa yang terjadi pada diri kamu sekarang merupakan dialektika sejarah, dalam hal ini adalah sejarah politik. Kamu tidak mungkin bisa lari dari cengkramannya. Kamu akan habis dikoyaknya." (Kubah, Hal 159)

Tokoh Karman dalam novel Kubah sebagai homo sacer adalah seseorang yang dikeluarkan dari masyarakat dan kehilangan semua hak dan fungsinya dalam kehidupan keagamaan dalam masyarakat. Dengan demikian, Karman adalah sosok manusia yang direduksi menjadi nihil perannya, tanpa hak, dan tanpa perlindungan. Karman sesuai dengan homo sacer yang dikemukakan Agamben (1998:65) bahwa homo sacer merupakan subjek yang didefinisikan oleh hukum, namun ia dikucilkan dan disingkirkan dari hukum.

\section{Bare Life yang tercermin pada tokoh Karman}

Pada kutipan berikutnya teridentifikasi sebagai bagian dari Bare Life yang tercermin pada tokoh Karman. Adapun perkataan yang membuat Karman semakin 
tenggelam dalam pengaruh politik Margo dan teman-temannya. Seperti dalam kutipan berikut:

"Mereka, orang-orang kaya, adalah kaum penindas yang secara historis selalu mempertahankan kelestarian kelasnya. Mereka tidak ingin seseorang seperti engkau masuk ke dalam kalangan mereka. Sadarlah kau sekarang, betapa jahat kaum tuan tanah itu." (Kubah, Hal 102-103).

Dalam kutipan diatas, menunjukkan bahwa Margo berusaha meyakinkan dan terus mendoktrin Karman untuk dapat membalaskan dendamnya kepada Haji Bakir. Margo mempengaruhi Karman bahwa untuk melestarikan kedudukannya orang-orang kaya selalu ingin menindas kaum miskin. Dalam waktu singkat, Karman pun dapat mengubah sikapnya dan mulai meninggalkan kebiasaannya menjalankan ibadah. Hal ini dapat ditemui dalam kutipan berikut.

"Hanya setahun sejak perkenalannya dengan kelompok Margo, perubahan besar terjadi pada diri Karman. Ia menjadi sinis. Segala sesuatu apalagi yang menyangkut Haji Bakir selalu ditanggapi dengan prasangka buruk. Karman pun semakin berterus terang meninggalkan masjid, meninggalkan peribadatan." (Kubah, Hal. 103).

Karman telah mengalami bare life, dimana ia telah terpengaruh dengan segala doktrin yang dilontarkan Margo dan temantemannya. Perubahan paling cepat dilakukan Karman adalah ia mulai meninggalkan kebiasaannya shalat dan tidak pernah menginjakan kakinya ke masjid.
Akan tetapi ketika Karman berada di pengasingan Pulau Buru, ia mulai mengingat akan hal-hal yang membuatnya terjerumus ke dalam partai komunis tersebut. Seperti dalam kutipan berikut.

"Aku tahu meskipun untuk mencapai tujuannya partai membenarkan segala cara, namun usaha itu ternyata gagal. Dan penggunaan cara yang tidak mempertimbangkan harkat kemanusiaan itu, sebenarnya kesadaranku tak bisa menerimanya. Andaikan sejak semula aku menyadari bahwa partai bisa melakukan makar yang begitu berlumuran darah seperti yang terjadi kemarin, sekali-sekali aku tak ingin menjadi anggota." (Kubah, Hal 179).

Kutipan di atas menunjukkan bahwa Karman tidak ingin menjadi seorang anggota partai komunis jika sebelumnya ia mengetahui cara kerja dan akibat keterlibatannya di partai komunis tersebut. Karman terpengaruh dengan doktrin yang dilontarkan Margo bahwa partai komunis dapat mensejahterakan kehidupannya. Margo dan Triman mencoba menjauhkan Karman dari hal-hal yang baik, dan terutama akan menjauhkan Karman dari Haji Bakir, seperti pada kutipan berikut.

"Jauhkan Karman dari Haji Bakir, dari masjidnya. Harus ditemukan cara untuk memisahkan Karman dari tuan tanah dan masjidnya itu." (Kubah, Hal 88).

Pada kutipan diatas, atasan Margo memerintahkan kepada Margo untuk agar Karman dapat menjauhi atau bahkan membenci Haji Bakir. Usaha Margo pun membuahkan hasil. Karman pun lamban laun 
menjauhi dari Haji Bakir dan menjauh dari Tuhan, serta tidak pernah sembahyang lagi. Karman memang tidak menduga bahwa ia akan dijadikan anggota partai komunis. Karman begitu polos, dan yang ia inginkan hanya untuk mendapatkan pekerjaan. Seperti pada kutipan berikut.

"Pemburuan dimulai. Halus sekali, tanpa letupan-letupan, bahkan tanpa nada kasar sedikit pun. Karman sungguh terlalu muda untuk menyadari bahwa sedang berlangsung kisah safari yang ditujukan kepada dirinya." (Kubah, Hal 89).

Mengacu pada kutipan di atas, jelaslah bahwa Karman dimanfaatkan oleh Margo dan teman-temannya agar mau menjadi anggota partai komunis. Memang Margo dan temantemannya memperlakukan Karman dengan baik. Doktrin yang dihembuskan Margo pun dilakukan dengan halus. Hal tersebut tidak membuat Karman berfikiran negatif dan menganggapnya seperti biasa saja. Bahkan Karman sama sekali tidak memandang negatif terhadap Margo dan teman-temannya. Padahal saat itu Karman berada di posisi yang membahayakan bagi dirinya, dan juga masyarakat Pegaten. Margo dan temantemannya bagaikan pemburu dan Karman sebagai mangsa yang lugu tanpa mencurigai siapapun yang akan memangsanya, seperti pada kutipan berikut:

"Pemburu dan mangsanya sudah berhadap-hadapan. Sungguh, tergambarlah dengan seksama kelicikan manusia di satu pihak dan keluguan di pihak lainnya." (Kubah, Hal 93).
Keterlibatan Karman dalam partai komunis sebenarnya tidak mengubah dirinya menjadi sosok yang lebih baik dan mempunyai kehidupan yang baik. Justru malah sebaliknya. Akhirnya Karman menjadi korban keluguannya dan menjadi sebagai tahanan politik, serta kehilangan segala haknya sebagai warga negara.

Meski demikian, pendoktrinan yang dilakukan Margo, Triman, dan temantemannya, membuat Karman merasa sangat menghargai, sehingga mengikuti apapun yang diperintahkan oleh Margo. Karman menjadi tidak sadar akan segala doktrin yang diterimanya. Dapat dilihat pada kutipan berikut.

"Sedikit pun ia tidak sadar adanya kekuatan tangan-tangan manusia yang sedang menariknya." (Kubah, Hal. 96).

Paham komunis yang dianut Margo dan teman-temannya sangat efektif dapat mempengaruhi Karman. Karman dibimbing dengan penuh tanggung jawab oleh para anggota partai komunis, agar menjadi kader yang mempunyai royalitas yang tinggi. Karman pun mendapatkan pelajaranpelajaran dari partai komunis. Tampak pada kutipan berikut.

"Kelompok Margo hanya memerlukan tambahan waktu untuk membina Karman lebih lanjut, tidak lebih. Melalui bukubuku yang diberikan kepada Karman, orang-orang partai berhasil menyusun dasar-dasar kejiwaan yang akan mempermudah mereka membina anak didik yang masih hijau itu menjadi pengikut mereka." (Kubah, hal 97-98). 
Melalui buku-buku yang diberikan orang-orang di Partai Komunis, doktrin komunis menjadi cepat diyakini dan mempengaruhi pikiran Karman. Para anggota partai politik itu berhasil membuat Karman berubah sikap. Bahkan Karman dapat membalaskan dendamnya terhadap perlakuan Haji Bakir. Hal ini tampak pada kutipan berikut.

"Apa yang diperbuat Karman adalah balas dendam. Ia merasa disakiti, dinista. Dengan meninggalkan masjid Haji Bakir, ia pun bermaksud membalas dendam. Bahkan ketika ia mulai sekali-dua meninggalkan sembahyang wajib, ia juga merasa sedang membayar kesumat." (Kubah, Hal 101).

Karman dapat membalas dendam kepada Haji Bakir, orang yang telah ikut membantu kehidupannya. Haji Bakir telah dianggap menjadi orang tua kedua untuk Karman sepeninggal bapaknya. Namun ketika anak Haji Bakir dinikahkan dengan orang lain dan menolak lamaran Karman, Karman pun menjadi kecewa. Margo dan teman-temannya menjadi penghubung balas dendam Karman kepada Haji Bakir. Mereka berpendapat bahwa kebaikan Haji Bakir kepada Karman itu palsu. Seperti tertera pada kutipan dibawah ini.

"Kebaikan yang pernah ia berikan kepadamu adalah contoh kemunafikan yang nyata. Takkan pernah ia menolongmu, menyantunimu ketika kau masih anak-anak, apabila ia tidak melihat keuntungan yang dapat di peroleh darimu." (Kubah, Hal 102).

\section{KESIMPULAN}

Mengacu pada konsep biopolitik modern yang dikemukakan Giorgio Agamben Tokoh Karman dalam novel Kubah karya Ahmad Tohari menunjukkan sosok individu yang seolah-olah memiliki identitas kewarganegaraan, namun terasa seperti tidak memiliki identitas. Akibat kesalahannya untuk memutuskan bergabung di partai komunis, ia menjadi kehilangan hak. Karman menjadi homo sacer, merasa menjadi manusia asing di desa Pegaten. Perubahan diri Karman yang semula sebagai individu yang lugu, religius serta taat beribadah, hingga menjadi seorang atheis merupakan sebuah proses bare life. Keputusannya untuk bergabung menjadi anggota partai komunis dan menjadi atheis diakuinya karena terhasut doktrin-doktrin yang dilontarkan oleh Margo, Triman, dan teman-temannya. Perubahan diri Karman untuk menjadi seorang yang jauh dari Tuhannya merupakan doktrin yang termanifestasi dan sudah ditentukan oleh partai komunis yang dimasukinya.

Ketika pemerintahan di Indonesia telah berganti, dan partai komunis pun telah ditumpas keberadaannya. Karman pun mulai merubah jalan hidupnya. Karman tidak ingin hak-haknya sebagai warga negara hilang. Karman pun tidak ingin orang-orang menyingkirkan keberadaannya sebagai warga dusun pegaten. Karman ingin kembali dianggap memiliki kedaulatan penuh atas haknya sebagai warga dusun Pegaten. Di akhir kisah dalam novel Kubah ini, Ahmad Tohari menggambarkan tokoh Karman menemukan cahaya kehidupan yang sempat hilang dan ia tinggalkan. Karman mendirikan 
kubah masjid dan warga dusun Pegaten pun

dapat kembali menerimanya sebagai individu yang keberadaannya memang diakui.

\section{DAFTAR PUSTAKA}

Wellek, R., \& Warren, A. (2016). Teori kesusastraan. Jakarta: Gramedia.

Agamben, G. (1998). Homo Sacer Sovereign Power and Bare Life. California: Stanford University Press.

Miles, M. B., Huberman, A. M., \& Sadana, J. (2014). Qualitative data analysis, a methods sourcebook, edition 3. Terjemahan Tjetjep Rohindi Rohidi, UIPress. USA: Sage Publications.

Tohari, A. (1995). Kubah. Jakarta: Gramedia Pustaka Utama.

Indrajaya, F. (2011). Homo Sacer sebagai figur politis dan kaitannya dengan dunia perguruan tinggi. Humaniora, 2(1), 335341.

Kaelan, M. S. (2012). Metode penelitian kualitatif interdisipliner. Yogyakarta: Paradigma.

Moleong, L. (2008). Metodologi penelitian kualitatif. Bandung: Remaja Rosdakarya.

Ratna, N. K. (2010). Metodologi penelitian: kajian budaya dan ilmu sosial humaniora pada umumnya. Yogyakarta: Pustaka Pelajar.

Salam, A. (2018). Sosiologi sastra postmarxisme. Yogyakarta: Dua enam. 